\title{
Late Pleistocene Vertebrate, Plant and Insect Remains from the Innerkip Site, Southwestern Ontario
}

Les restes de vertébrés, de végétaux et d'insectes au site d'Innerkip dans le sud-ouest de l'Ontario

Wirbeltier-, Pflanzen- und Insekten-Reste aus dem späten Pleistozän von dem Innekip Fundort, süd-westliches Ontario

\author{
Charles S. Churcher, Jerry J. Pilny et Alan V. Morgan
}

Volume 44, numéro 3, 1990

The Last? Interglaciation in Canada

Le dernier (?) interglaciaire au Canada

URI : https://id.erudit.org/iderudit/032831ar

DOI : https://doi.org/10.7202/032831ar

Aller au sommaire du numéro

\section{Éditeur(s)}

Les Presses de l'Université de Montréal

\section{ISSN}

0705-7199 (imprimé)

1492-143X (numérique)

\section{Découvrir la revue}

Citer cet article

Churcher, C. S., Pilny, J. J. \& Morgan, A. V. (1990). Late Pleistocene Vertebrate, Plant and Insect Remains from the Innerkip Site, Southwestern Ontario. Géographie physique et Quaternaire, 44(3), 299-308.

https://doi.org/10.7202/032831ar
Résumé de l'article

Les restes de cerf de Virginie (Odocoileus virginianus), de campagnols des champs (Microtus pennsylvanicus), de rat musqué (Ondatra zibethicus) et de tortue mouchetée (Emydoidea blandingi) ont été recueillis dans un dépôt de tourbe à découvert d'un tributaire de la rivière Thames. De nombreux fossiles d'insectes, surtout de coléoptères, et une certaine variété de végétaux faisant partie du même horizon stratigraphique ont permis de faire la reconstitution, du moins partielle, d'une communauté plus importante au site de la mise en place de la tourbe. Les fossiles de végétaux, de vertébrés et d'invertébrés représentent une partie d'un regroupement qui a vécu dans un petit étang ou à proximité. La mise en place a probablement eu lieu à la fin de l'Interglaciaire du Sangamonien (stade isotopique 5e) ou au cours d'un interstade chaud du Wisconsinien inférieur (stade isotopique 5c ou 5a). 


\section{LATE PLEISTOCENE VERTEBRATE, PLANT AND INSECT REMAINS FROM THE INNERKIP SITE, SOUTHWESTERN ONTARIO*}

Charles S. CHURCHER, Jerry J. PILNY and Alan V. MORGAN: first author, Department of Zoology, University of Toronto, Ontario M5S 1A1 and Royal Ontario Museum, Toronto, Ontario M5S 2C6; second and third authors, Quaternary Sciences Institute and Department of Earth Sciences, University of Waterloo, Waterloo, Ontario N2L 3G1.

ABSTRACT Remains of white-tailed deer (Odocoileus virginianus), meadow voles (Microtus pennsylvanicus), muskrat (Ondatra zibethicus) and Blanding's turtle (Emydoidea blandingi) have been recovered from a peat deposit exposed on a tributary of the Thames River in southwestern Ontario. Numerous insect fossils, principally Coleoptera, and a variety of plants recovered from the same stratigraphic horizon have permitted a partial reconstruction of a larger community at the site of peat deposition. The plant, vertebrate and invertebrate fossils represent part of an assemblage which existed in, or beside, a small pond. Deposition probably occurred at the end of the Sangamon Interglaciation (Isotope Stage 5e) or during warm Early Wisconsinan interstadial (Isotope Stage $5 \mathrm{c}$ or 5a).
RÉSUMÉ Les restes de vertébrés, de végétaux et d'insectes au site d'Innerkip dans le sud-ouest de l'Ontario. Les restes de cerf de Virginie (Odocoileus virginianus), de campagnols des champs (Microtus pennsylvanicus), de rat musqué (Ondatra zibethicus) et de tortue mouchetée (Emydoidea blandingi) ont été recueillis dans un dépôt de tourbe à découvert d'un tributaire de la rivière Thames. De nombreux fossiles d'insectes, surtout de coléoptères, et une certaine variété de végétaux faisant partie du même horizon stratigraphique ont permis de faire la reconstitution, du moins partielle, d'une communauté plus importante au site de la mise en place de la tourbe. Les fossiles de végétaux, de vertébrés et d'invertébrés représentent une partie d'un regroupement qui a vécu dans un petit étang ou à proximité. La mise en place a probablement eu lieu à la fin de l'Interglaciaire du Sangamonien (stade isotopique $5 \mathrm{e}$ ) ou au cours d'un interstade chaud du Wisconsinien inférieur (stade isotopique $5 \mathrm{c}$ ou $5 \mathrm{a}$ ).
ZUSAMMENFASSUNG Wirbeltier-, Pflanzen- und Insekten-Reste aus dem späten Pleistozän von dem Innekip Fundort, südwestliches Ontario. Reste von Virginia-Hirsch (Odocoileus virginianus), Wiesenmäusen (Microtus pennsylvanicus), Bisamratte (Ondatra zibethicus) und Blading's Schildkröte (Emydoidea blandingi) wurden aus einer Torfablagerung wiedergewonnen, die an einem Nebenfluss des Thames River offengelegt war. Zahlreiche Insekten-fossile, hauptsächlich Coleoptera, und eine Vielfalt von Pflanzen von demselben stratigraphischen Horizont erlaubten eine teilweise Rekonstruktion einer grösseren Lebensgemeinschaft am Ort der Torfablagerung. Die Fossile von Pflanzen, Wirbeltieren und Wirbellosen sind Teil einer Einheit, die in oder neben einem kleinen Teich existierte. Die Ablagerung fand wahrscheinlich am Ende des sangamonischen Interglazial (Isotop Stadium $5 e)$ oder während des frühen Wisconsinischen Interstadial (Isotop Stadium $5 \mathrm{c}$ oder 5a) statt.

\footnotetext{
* Quaternary Entomology Laboratory Contribution No. 109

Manuscrit reçu le 31 juillet 1989; manuscrit révisé accepté le 14 septembre 1989
} 


\section{INTRODUCTION}

Vertebrate remains are uncommon in the Quaternary deposits of southwestern Ontario. Most of the finds derive from surficial deposits, and often represent the remains of larger mammals such as mastodonts (Mammut americanum; Dreimanis, 1967), mammoths (Mammuthus spp.; McAndrews and Jackson, 1988), grizzly bear (Ursus arctos; Peterson, 1965) or deer (Torontoceras hypogaeus; Churcher and Peterson, 1982) which had recolonised the recently deglaciated Late Wisconsinan terrain. Animal remains recovered in situ from interstadial or interglacial sites are exceedingly rare, and often consist of bones and teeth of large animals such as grizzly bear (Ursus arctos; Churcher and Morgan, 1976), musk-ox (Ovibos moschatus; Churcher and Karrow, 1977), elk-moose (Cervalces borealis), or giant beaver (Casteroides ohioensis; Harington, 1978). Almost all of these finds were from within the older Wisconsinan or Sangamonian deposits of the Toronto region.

Recent examination of organic levels in a section exposed on Timm's Creek (Innerkip Site), near Woodstock, Ontario (Pilny and Morgan, 1987) entailed sorting hundreds of kilograms of peaty detritus from non-glacial strata beneath Late Wisconsinan tills. This paper describes teeth and bone fragments recovered from the peaty deposit during a search for coleopteran remains. The paper also summarises some of the Coleoptera and plant remains previously described and comments on the ecological relationships of the plants and animals recognised at the site.

\section{SITE LOCATION}

The Innerkip site is situated $50 \mathrm{~km}$ northeast of London, Ontario (Fig. 1) at $43^{\circ} 10^{\prime} \mathrm{N}, 80^{\circ} 43^{\prime} \mathrm{W}$. The cutbank section which yielded the vertebrate remains described here lies on the southwest side of Timm's Creek, a tributary of the Thames River, $3 \mathrm{~km}$ from the village of Innerkip in lot 6, concession XV, East Zorra Township, Oxford County (Pilny and Morgan, 1987).

\section{STRATIGRAPHY AND RADIOCARBON CHRONOLOGY}

W.R. Cowan located the Innerkip site during regional mapping in the early 1970s, and later described the stratigraphy (Cowan, 1975). He recognised two tills overlying lacustrine silts which in turn rested upon a $1 \mathrm{~m}$ thick stratum of organic debris (Fig. 2). The upper $60 \mathrm{~cm}$ is black organic mud with very few animal or plant remains. The lower $40 \mathrm{~cm}$ consists of highly compressed peat with numerous insect fragments and pieces of wood. The peat is underlain by approximately $2 \mathrm{~m}$ of grey silty clay which rests unconformably on Devonian bedrock (Fig. 3).

Analyses of the bryophyte macrofossils in the peat were conducted by M. Kuc of the Geological Survey of Canada, Ottawa (M. Kuc, Bryological Report No. 245, 1973; No. 265. 1974 ) and the pollen was examined by J. Terasmae of Brock University, St. Catharines, Ontario (Cowan et al., 1975). Their findings suggested that the sequence was at least as old as Middle Wisconsinan (Cowan et al., 1975). Bulk samples of peat were also analysed by the Department of Geological Sciences, Brock University (BGS) and the Geological Survey of Canada, Ottawa (GSC). The radiocarbon ages obtained are listed in Table I (Lowdon et al., 1977).

The infinite dates (oldest $>50,000 \mathrm{yr}$. BP) are probably more reliable, since the younger, finite ages likely represent sample contamination, or differences in laboratory pretreatment. We presume that the Innerkip organics were deposited during, or before, the Port Talbot I Interstadial.

A recent interpretation, based largely upon fossil Coleoptera recovered from the peat, is that the peat was deposited in a climate similar to that of southern Ontario today (Pilny and Morgan, 1987). The implication is that the site may represent a very warm Wisconsinan interstadial (i.e. Early Wisconsinan, possibly Port Talbot I), or may be of Sangamonian (last interglacial) age. Here, and in Pilny and Morgan (1987), the terminology used implies that the "Sangamonian" sensu stricto, is Isotope Stage $5 \mathrm{e}$, whilst the "warm" stages $5 \mathrm{c}$ and $5 \mathrm{a}$, are regarded as Early Wisconsinan (St-Onge, 1987).
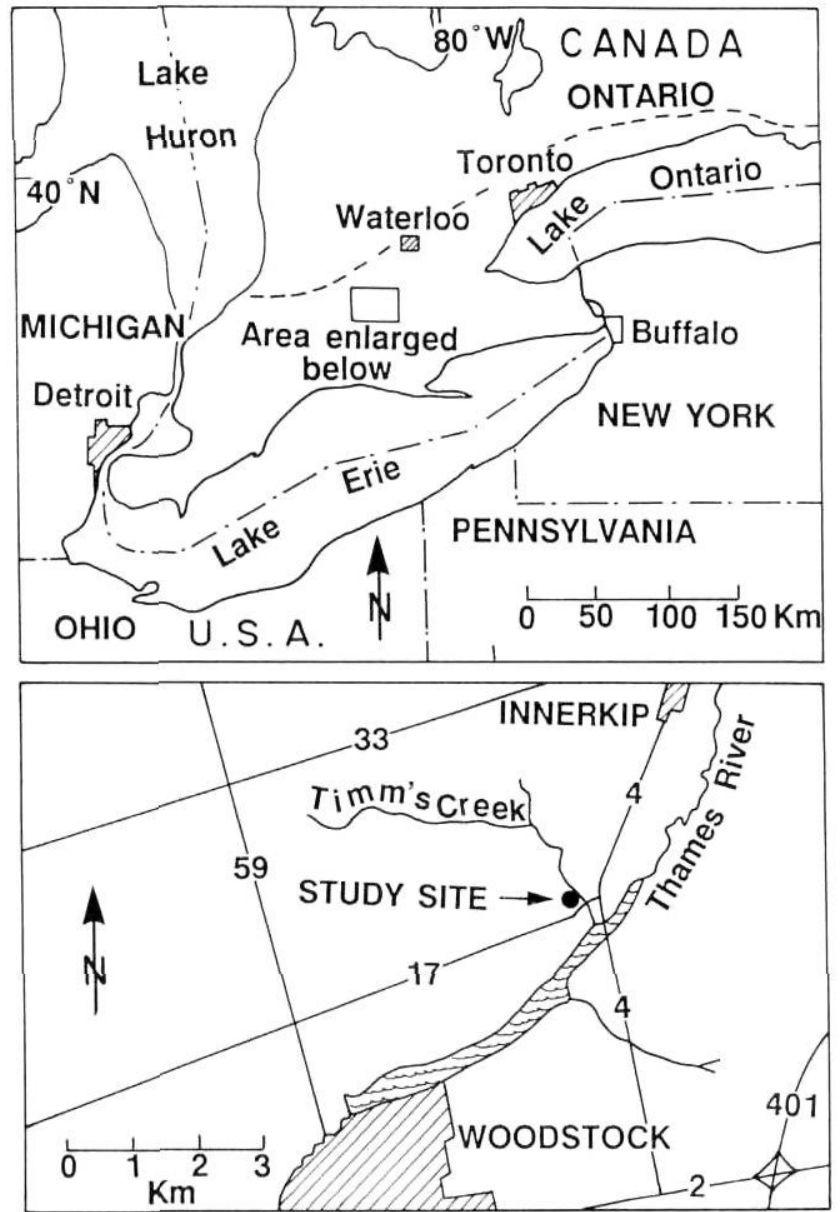

FIGURE 1. Location of the Innerkip site on Timms Creek, northeast of Woodstock, Ontario. Dashed line indicates boundary between southerly Carolinian and northerly Hudsonian faunal zones (after Pilny and Morgan, 1987).

Localisation du site d'Innerkip sur le Timms Creek, au nord-est de Woodstock, en Ontario. Les traits montrent la limite entre les zones fauniques carolinienne, au sud, et hudsonienne, au nord (selon Pilny et Morgan, 1987). 


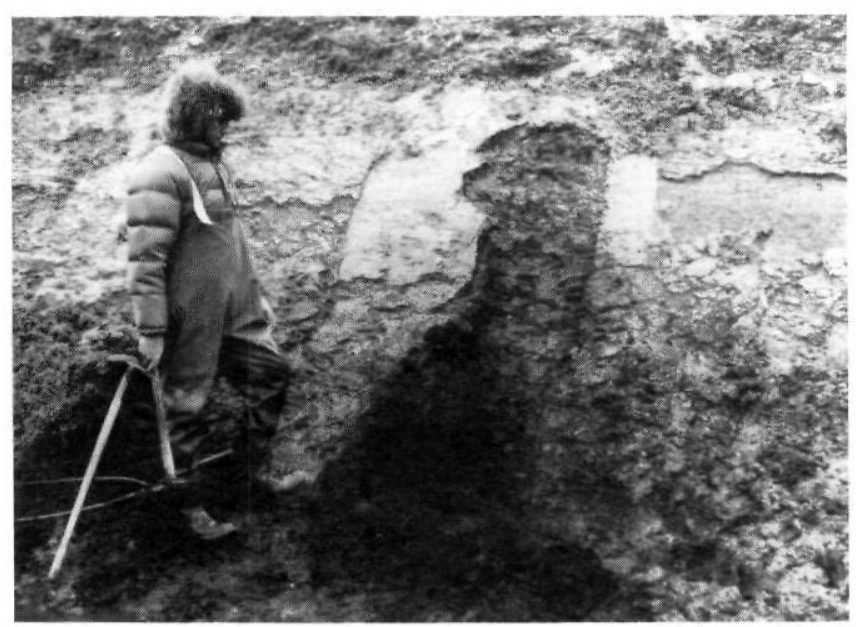

FIGURE 2. The Innerkip section at winter (stream) level. The dark coloured peat in which the vertebrate, plant and invertebrate remains were found can be clearly seen at the base of the section.

La coupe d'Innerkip (niveau hivernal). La tourbe de couleur sombre dans laquelle les restes de vertébrés, de végétaux et d'invertébrés ont été trouvés se reconnaît facilement à la base de la coupe.

\section{SAMPLING AND PROCESSING}

Over $475 \mathrm{~kg}$ of sediment were extracted from a cleaned face of the section, and bagged for laboratory processing. The sediment was soaked in water to facilitate disaggregation and then washed through a $300 \mu \mathrm{m}$ sieve. Material retained on the sieve was separated into light (organic) and heavy (sandy) fractions by water flotation. The heavy fraction was sorted with forceps under a low power binocular microscope for bones, teeth and wood. The peat horizon (fig. 2) contained the richest insect, plant and vertebrate assemblage and all subsequent work concentrated on this stratum. The light fraction was further separated by the kerosene flotation method originally described by Coope (1968) and more recently by Morgan (1988). All specimens are stored in the Quaternary Entomology Laboratory, Department of Earth Sciences, University of Waterloo. The materials listed in Table II are uncatalogued and the numbers should be considered as field or accession numbers only.

\section{SYSTEMATIC PALAEONTOLOGY (VERTEBRATES)}

Odocoileus virginianus (Zimmerman) - white-tailed deer

The white-tailed deer Odocoileus virginianus (Zimmerman) is identified on a right lower first incisor (Fig. 4a-b), and possibly represented by some of the longbone fragments. The crown measures $3.0 \mathrm{~mm}$ in mesiodistal and $2.8 \mathrm{~mm}$ in buccolingual diameters, $7.0 \mathrm{~mm}$ in height on the buccal surface from the enamel margin to the worn incisive edge; the root measures 6.6 by $2.9 \mathrm{~mm}$ in greater and lesser diameters of the neck.

This species lives in much of North America exclusive of the boreal tundra, taiga and coniferous forests, preferring mixed hardwood forests in which glades with poplars, aspens and birches predominate.

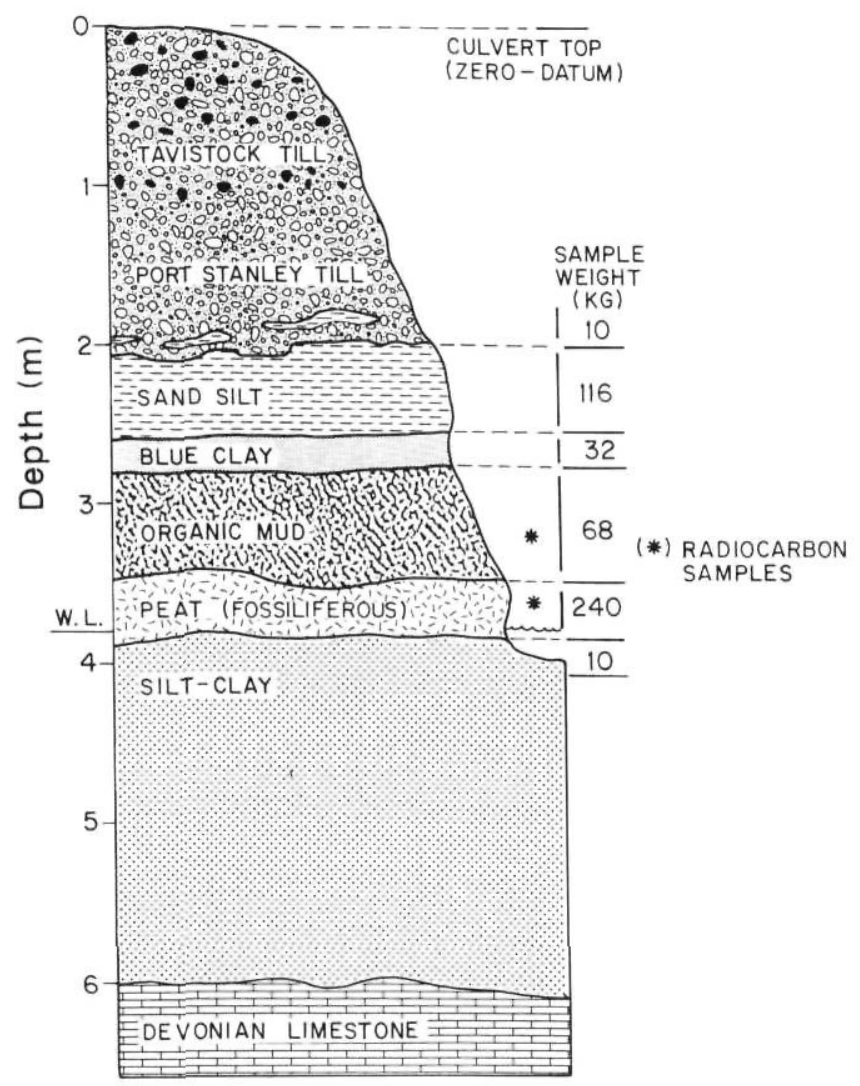

FIGURE 3. Stratigraphic section at the Innerkip site. Vertebrate fossils were recovered from the peat member between 3.5 and $3.9 \mathrm{~m}$ below grade (after Pilny and Morgan, 1987).

Coupe stratigraphique au site d'Innerkip. Les fossiles de vertébrés ont été trouvés dans la tourbe entre 3,5 et 3,9 m de profondeur (selon Pilny et Morgan, 1987).

TABLE I

Radiocarbon dates from the Innerkip site

\begin{tabular}{ccc}
\hline Laboratory number & Radiocarbon age (yr BP) & Material dated \\
\hline BGS-134A & $33,670 \pm 830$ & Black organic mud \\
GSC-2010 & $>42,000$ & Black organic mud \\
GSC-2010-2 & $>50,000$ & Black organic mud \\
MGS-134B & $33,230 \pm 610$ & Peat \\
GSC-1884 & $>43,000$ & Peat \\
\hline
\end{tabular}

Wilson and Hills (1984) report that the species is sensitive to deep snow and low temperatures, and its presence may be an indicator of climatic limitations of temperature and snowfall. Holocene fossils of this species are numerous in the Great Lakes region and many sites in the eastern United States and Canada (Harington, 1978; Kurtén and Anderson, 1980). However, because this species occurs from Florida north to Lake Superior, its presence at the Innerkip Site suggests that the temperatures were not extreme in winter and that coniferous forest was not dominant. 
Ondatra zibethicus (Linnaeus) - muskrat

The muskrat Ondatra zibethicus (Linnaeus) is identified on an unrooted left upper third molar ( $1 \mathrm{M}^{3}$, Fig. $\left.4 \mathrm{c}-\mathrm{d}\right)$, some molar fragments, and possibly represented within the indeterminate materials. The molar originally measured $4.0 \mathrm{~mm}$ in mesiodistal and $2.3 \mathrm{~mm}$ in buccolingual diameters, but is now broken.

The muskrat is common over much of North America (Hall, 1981), including all of Ontario (Peterson, 1966). It feeds on freshwater mussels or "clams" (Anodonta grandis), and on the shoots and roots of aquatic vegetation such as Nymphaea, Potamogeton, Sparganium and Sagittaria (Zichmanis and Hodgins, 1982). All of the plants cited above have been identified within the peaty layer at the Innerkip site.

Microtus pennsylvanicus (Ord) - meadow vole.

The vole (Microtus pennsylvanicus, Fig. $4 \mathrm{e}-\mathrm{g}$ ) is both the most abundantly represented mammal, and probably the most numerous by individuals. It is recognised on its prismatic molars and enamel loops (Banfield, 1974), and little else other than incisor fragments is preserved at the site.

Species of Microtus occur throughout North America (Hall, 1981) and two species Microtus pennsylvanicus (meadow

TABLE ॥

Vertebrate remains from the Innerkip Site

Odocoileus virginianus - white-tailed deer

1. Right lower 1 st incisor $\left(\mathrm{rl}_{1}\right)$; Figure $4(\mathrm{a}, \mathrm{b})$.

2. Premolar or molar fragments; indeterminate.

Ondatra zibethicus - muskrat

3. Left upper 3rd molar $\left(\mathrm{IM}^{3}\right)$, unworn. Figure 4 (c, d).

4. Fragments of large microtine cheek teeth.

Microtus pennsylvanicus - meadow vole.

5. Right upper second molar $\left(\mathrm{rM}^{2}\right)$. Figure $4(\mathrm{e}, \mathrm{f}, \mathrm{g})$.

Microtus sp. - voles

6. Two microtine molar fragments.

7. Fragments of microtine cheek teeth.

8. Right upper incisor ( $\mathrm{rl}^{\prime}$ ) fragments.

9. Upper and lower incisor fragments.

10. Right humerus, distal section of shaft.? Microtine.

Emydoidea blandingi - Blandings's turtle

11. Right third marginal plate of carapace; lateral portion

12. Right fourth marginal plate of carapace; medial portion.

13. Hypoplastron plate fragment within anterior sutural margin. Figure 4 (h, i).

14. Fragments of carapace or plastron plates; indeterminate.

Carnivora - carnivores.

15. Fragment of incisor or canine.? Small mustelid.

Fragmentary material.

16. Longbone shaft fragment; from a medium to large mammal.

17. Tibiofibula, distal shaft section; from a small rodent or shrew.

18. Two longbone shaft fragments; from a small mammal or bird?

19. Four bone fragments; from mammal or reptile? vole) and $M$. pinetorum (= Pitymys pinetorum, pine mouse), currently inhabit the Woodstock/Innerkip area (Peterson, 1966). $M$. pennsylvanicus is represented by one complete right upper second molar, some incisor and cheek teeth fragments, and possibly postcranial elements. The molar measures $1.5 \mathrm{~mm}$ in mesiodistal and $1.1 \mathrm{~mm}$ in buccolingual diameters.

M. pennsylvanicus is widespread in southern Ontario today, but $M$. pinetorum is restricted to the Carolinian zone north of Lake Erie (Peterson, 1966).
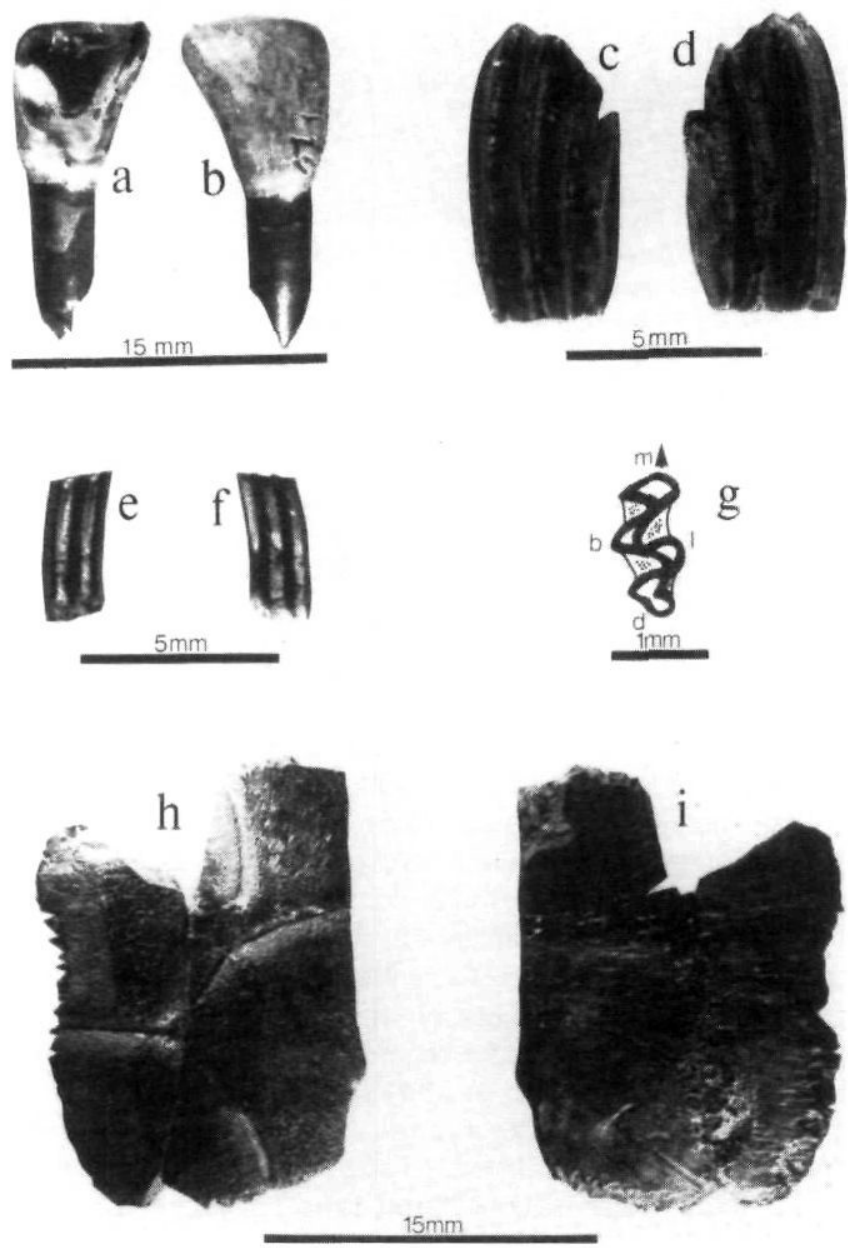

FIGURE 4. Vertebrate fossils from the Innerkip site (scale in $\mathrm{mm}$ as indicated): Odocoileus virginianus: right lower first incisor $\left(\mathrm{rl}_{1}\right)$; (a) lingual and (b) buccal aspects; Ondatra zibethicus: damaged left upper third molar $\left(1 \mathrm{M}^{3}\right)$; (c) buccal and (d) lingual aspects, with unworn crown to bottom, and open roots to top of the figure: Microtus pennsylvanicus: right upper second molar $\left(\mathrm{rM}^{2}\right)$; (e) lingual and (f) buccal aspects, (g) diagram of occlusal enamel pattern (thick black lines). Abbreviations: arrow $=$ anterior $; m=$ mesial; $d=$ distal; $b=$ buccal and $\mathrm{I}$ = lingual aspects; Emydoidea blandingi: Hypoplastron plate. (h) external and (i) internal aspects.

Les fossiles de vertébrés au site d'Innerkip: Odocoileus virginianus: première incisive inférieure droite; (a) côté lingual et (b) côtè vestibulaire; Ondatra zibethicus: troisième molaire superieure gauche endommagée, (c) côté lingual et (d) côté vestibulaire, avec couronne non usee (en bas) et racines ouvertes (en haut); Microtus pennsylvanicus: deuxième molaire supérieure droite (e) côté lingual et (f) côté vestibulaire, $(g)$ schéma du plan d'occlusion de l'émail (traits noirs épais) Abréviations: flèche = antérieur; $m=$ médian; $d=$ distal, $b=$ côté vestibulaire, I = côté lingual.; Emydoidea blandingi: côté interne (h) et côté externe (i) du plastron. 


\section{Emydoidea blandingi (Holbrook) - Blanding's Turtle}

Blanding's turtle (Emydoidea blandingi) is represented by portions of the carapace and hypoplastron (Fig. $4 \mathrm{~h}-\mathrm{i}$ ). It is the least widespread taxon identified in the Innerkip local fauna. The turtle is found today in Ontario south of the French River, along the southern shores of lakes Ontario and Erie, west as far as Nebraska, and northwest to Duluth on Lake Superior, but not on the upper peninsula of Michigan or on the western shore of Lake Michigan (Fig. 5, Behler and King, 1979). An isolated population exists in Connecticut and Rhode Island, and in neighbouring parts of the states of Massachusetts, New Hampshire and New York, including Long Island.

The habitat in which it is found is deciduous mixed hardwood forest with streams, ponds and swamps: it does not occur in the coniferous boreal forest or its outliers. The northern limit of its range in Ontario is approximately coincident with the $4^{\circ} \mathrm{C}$ mean annual isotherm.

\section{Other vertebrate materials}

The remaining specimens are not able to be identified with any certainty.

A fragment of a small tooth appears to represent part of a lower incisor or canine of a small carnivore, possibly a mustelid. Three species of Mustela, i.e., M. erminea (ermine), M. frenata (long-tailed weasel) and $M$. vison (mink) today inhabit southern Ontario (Peterson, 1966). It is possible that one of them may be represented, and the mink, which is often found near water, is the most likely.

The numerous fragmentary specimens are uninformative except to suggest that the microfauna is relatively abundant within the peat, should it be sampled further, and that additional materials would add to the certainty of the identifications and the possibility of identifying further taxa such as the shrews, small rodents or birds. The absence of some taxa, e.g., Anura (frogs and toads), is puzzling, but may reflect their fragile bones or chance lack of preservation.

\section{ADDITIONAL FOSSIL MATERIALS FROM INNERKIP}

\section{PLANTS}

Plant material is common, but usually not well preserved, in the Innerkip site. Various samples have been recovered at different times for pollen, moss, seeds and wood, but poor preservation of most material (except for seeds) has limited the floral list and the interpretation of the plant assemblages.

Pollen was originally analysed by J. Terasmae, and reported in Cowan (1975). Preservation in the peat is poor; just 103 grains were counted with 55 representing pine (Pinus), 9 belonging to spruce (Picea), 3 from fir (Abies), 13 were oak (Quercus), 11 were from various deciduous trees; birch, willow and linden (Betula, Salix and Tilia), and the remainder (12 grains) were non-arboreal.

Mosses were recovered from both the peat (described as a mossy sapropel) and the overlying fine pelitic detrital sapropel (M. Kuc, G.S.C. Bryological Report No. 245, 1973; No. 265 , 1974). Only the moss fragments from the peat were assigned

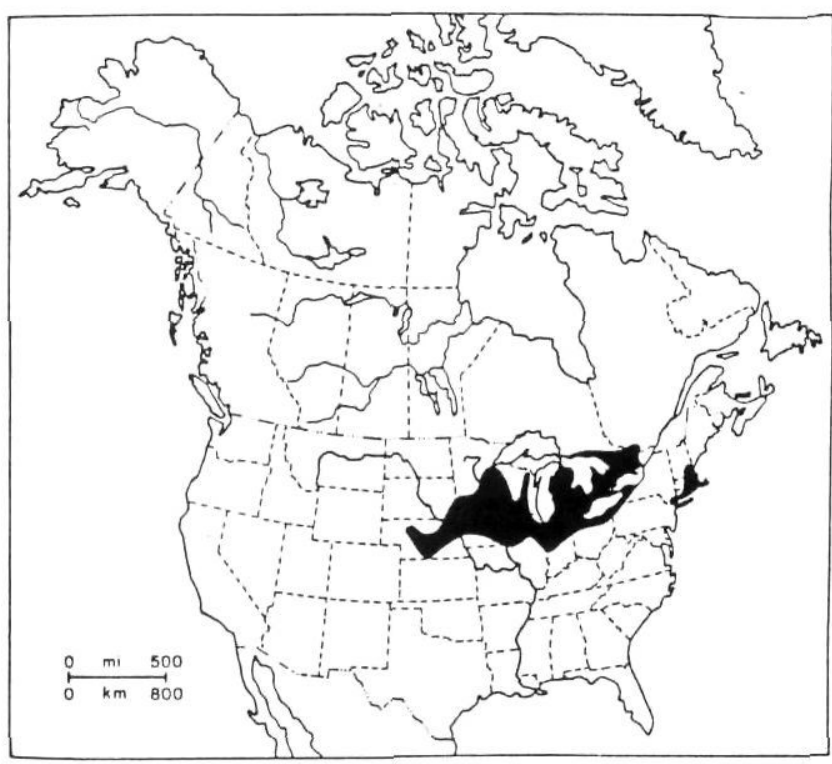

FIGURE 5. Distribution of Blanding's turtle (Emydoidea blandingi Holbrook; from Behler and King. 1979).

Répartition de la tortue mouchetée (Emydoidea blandingi Holbrook; de Behler and King, 1979).

a generic name (Drepanocladus), and Kuc suggested that these might belong to Drepanocladus exannulatus and/or D. fluitans.

Wood fragments (up to $7 \mathrm{~cm}$ long) were recovered from the - peat, and an attempt was made to analyse the material with the use of thin sections. The wood fragments appear to be from deciduous trees, and one $11 \mathrm{~cm}$ sample submitted by Cowan was identified as willow (Salix sp.) (L. D. Wilson, Geological Survey of Canada, Wood Identification Report No. 75-3).

Over 500 seeds were identified from organic material which floated during the kerosene separation for insect chitin. At least 16 families of plants are represented (Table III), and most are from species found in shallow water and shoreline environments. Almost $70 \%$ of the seeds recovered were from six genera; spikerush (Eleocharis), watershield waterlily (Brasenia), bullhead lily and white waterlily (Nuphar and Nymphaea), sedge (Carex) and water nymph (Najas). Eighteen seeds of white birch (Betula papyrifera) were found in samples processed for insects. Unfortunately, all of the plant species identified are quite cosmopolitan (ranging as far north as treeline), and little inference can be drawn in respect to climate.

\section{INSECTS}

Insects recovered from the Innerkip site were represented by a number of orders including ants (Hymenoptera), true bugs (Hemiptera), caddisflies (Trichoptera) and beetles (Coleoptera). The beetle fauna was by far the best represented (95\% of total fragments recovered), and over 2,000 individuals from 120 genera and 19 families were identified. The faunal list is given in Table IV. About $80 \%$ of identified fauna were members of four families; water scavenger beetles (Hydrophilidae), weevils (Curculionidae), rove beetles (Staphylinidae), and ground beetles (Carabidae). 
TABLE III

Seeds recovered from the Innerkip site

Family: genus and species

\section{Alismataceae:}

Sagittaria latifolia

Broad-leafed arrowhead

$(6 \%)$

Betulaceae:

Betula papyrifera

White birch

Ceratophyllaceae:

Ceratophyllum cf. demersum Coon-tail

\section{Cyperaceae:}

Carex

Eleocharis spp.

Scirpus fluviatilis

Scirpus validus

Scirpus sp

\section{Gentianaceae:}

Menyanthes trifoliata

Haloragaceae:

Myriophyllum sp.

Hypericaceae:

Hypericum sp.

Labiatae:

Mentha sp.

Najadaceae:

Najas flexilis

Potamogeton spp.

\section{Nymphaeaceae:}

Brasenia schreberi

Nuphar cf. variegatum

Nymphaea cf. advena

Nymphaea tuberosa

Nuphar/Nymphaea spp.

Polygonaceae:

Polygonum

Ranunculaceae:

Ranunculus aquatilis

Sedge

Spikerush

Bullrush

$(9.5 \%)$

(22.5\%)

Water milfoil

St. John's wort

Spearmint

Water nymph

Pondweed

$(8.7 \%)$

$(4.7 \%)$

Water-shield waterlily

Bullhead Lily

White waterlily

(All Above combined)

Smartweed

White water-buttercup

Rosaceae:

Rubus sp.

\section{Sparganiaceae:}

Sparganium chlorocarpum

Slender bur-reed

Umbelliferae:

Gen. indet.

Verbenaceae:

Verbena sp.

Vervain
The fossil Coleoptera assemblage is typical of beetle communities collected today in marshes and at the borders of water. Members of families not mentioned above (Limnebiidae, Pselaphidae, Leiodidae, Scaphidiidae, Orthoperidae and certain terrestrial Hydrophilidae) are hygrophilous, and are almost always found in wet and decaying vegetation. Weevils such as Bagous, Onychylis and Tanysphirus live on aquatic vegetation (Tanysphirus on duckweed), while the leaf beetles Donacia and Plateumaris are sedge-eaters.

Many of the ground beetles, including most of the Bembidion species, Carabus vinctus, Oodes amaroides and Blethisa quadricollis are hygrophilous, and the same may be said for nearly all the rove beetles recovered from the site.

A full discussion of the coleopteran fauna from the Innerkip site is given in Pilny and Morgan (1987).

\section{DISCUSSION AND CONCLUSIONS}

The presence of white-tailed deer (Odocoileus virginianus), and Blanding's turtle (Emydoidea blandingi) indicate that the area around Innerkip and Woodstock at the time of the deposit, $(>50,000 \mathrm{yr}$. BP) had a climate in which deep snow was not prevalent in winter, with a mean temperature of $4^{\circ} \mathrm{C}$, or higher, and was wooded with mixed hardwoods and forbs similar to those in southern Ontario today.

Blanding's turtle has a preference for shallow, marshy waters and ponds with a soft bottom and plenty of aquatic vegetation. It is often found foraging in water barely shallow enough to cover its shell, and is frequently seen basking on muskrat houses (another species recorded at the site). The main food supply for the turtle consists of minnows, tadpoles, crustaceans, and aquatic plants.

The presence of muskrat (Ondatra zibethicus) shows that standing or running water was present year round, and in sufficient quantities to support the various aquatic vegetation required for its food. The identification of the meadow vole (Microtus pennsylvanicus) gives little additional climatic information. Thus the climate of the bog that is represented by the vertebrate fossils at the Innerkip Site is identifiable as very similar to that in the area today.

The evidence from the plant remains and Coleoptera support the view of a temperate continental climate with reasonable rainfall (ca. $850 \pm 50 \mathrm{~mm}$ ). Such a climate could have existed at the end of the Sangamon Interglaciation during the climatic deterioration at the onset of the Wisconsin Glaciation. However, the fauna and the flora suggest that the bog was well established, and was not periglacial.

Certainly the plant remains indicate that the vegetation was broadleaf forest and thus relatively warm. The pollen evidence does not reflect the presence of a boreal forest, and the phytophagous beetles agree with this interpretation. The limited number of scolytids (only seven individuals from three genera) is also a good indication that the site was not in the vicinity of a spruce/pine forest. In typical late-glacial southern Ontario assemblages it is not unusual to recover hundreds of boreal scolytids from relatively small samples. Many of the weevils 
TABLE IV

Taxonomic list of Coleoptera from the Innerkip site

Taxon (skeletal parts)

$M N L^{1} \mathrm{NLE}^{2} \mathrm{NRE}^{3} \mathrm{NPR}^{4} \mathrm{NHE}^{5} \mathrm{NFR}^{6}$

\section{CARABIDAE}

Agonum cf. aeruginosum Dej.

A. melanarium Dej. group

A. mutatum G. \& H./corvus LeC.

A. cf. mutatum LeC.

A. placidum Say

Agonum spp.

cf. Agonum sp.

cf. Amara sp.

cf. Asaphidion sp.

Bembidion cf. concolor, Kby.

B. concretum Csy.

B. concretum Csy./fortestriatum Motsch./pseudocutum Lth.

B. cf. concretum Csy.

B. cf. concretum Csy./versicolor LeC.

B. fortestriatum Motsch.

B. cf. fortestriatum Motsch.

B. subgenus Furcacampa Net.

B. cf. nigripes Kby.

B. patruele Dej.

B. subgenus Plataphodes Gngib.

B. subgenus Semicampa Net.

B. transparens Gebl.

B. cf. transparens Gebl.

B. cf. versicolor LeC.

Bembidion spp.

Blethisa quadricollis Hald.

Blethisa sp.

Carabus vinctus Web.

Chlaenius pensylvanicus Say

Chlaenius sp.

cf. Chlaenius sp.

Clivina sp.

Cymindis sp.

Dyschirius spp.

Elaphrus clairvillei Kby.

Elaphrus olivaceus LeC.

Loxandrus sp.

cf. Loxandrus sp.

Oodes amaroides Dej.

Oodes spp.

Patrobus longicornis Say

Patrobus cf. Iongicornis Say

$P$. cf. stygicus Chd./lecontei Chd

Patrobus sp.

cf. Patrobus sp.

Pterostichus mutus Say

$P$. cf. patruelis Dej.

cf. Pterostichus sp.

Stenolophus cf. fuliginosus Dej.

cf. Trechus sp.

Carabidae gen. indet.

Carabidae total

HALIPLIDAE

gen. indet.

DYTISCIDAE

Acilius spp.

cf. Agabus sp.

Colymbetes spp.

Hydroporus spp.

Taxon

(skeletal parts)

$\mathrm{MNL}^{1} \mathrm{NLE}^{2} \mathrm{NRE}^{3} \mathrm{NPR}^{4} \mathrm{NHE}^{5} \mathrm{NFR}^{6}$

Hygrotus sp.

Liodessus flavicollis LeC.

Rhantus sp.

Dytiscidae gen. indet.

Dytiscidae total

GYRINIDAE

Gyrinus spp.

HYDROPHILIDAE

Berosus spp.

Cercyon cf. marinus Thoms.

Cercyon cf. pretextatus Say

Cercyon sp. " $\mathrm{X}$ "

cf. Crenophilus sp.

cf. Enochrus/Cymbiodata spp.

Helophorus nitiduloides D'Orch.

Helophorus spp.

cf. Hydrobius sp

Hydrochus sp.

Paracymus despectus LeC.

Paracymus cf. subcupreus Say

Tropisternus spp.

Hydrophilidae gen. indet.

Hydrophilidae total

LIMNEBIIDAE

Hydraena spp.

Ochthebius spp

STAPHYLINIDAE

Acidota crenata Fab.

A. quadrata Grav.

A. subcarinata Erich

Acylophorus pronus Erich.

Acylophorus sp.

subfamily Aleocharinae

subfamily Aleocharinae/Oxytelinae

Anaquedius vernix Csy.

Carpolamus spp.

Carpoamus/Thenobius sp.

Erichsonius sp.

Euaesthetus sp.

Eucnecosum sp

Gabrius sp.

Gymnusa sp.

Lathrobium spp.

Micropeplus cribratus LeC.

Myllaena spp.

cf. Myllaena sp.

Olophrum consimile Gyll.

Olophrum spp.

subfamily Omaliinae

Philonthus sp.

cf. Philonthus sp.

Philonthus/Gabrius sp.

cf. subfamily Quediini

Quedius sp.

Stenus advena Csy.

S. cf. advena Csy

S. alexanderi Puthz

S. cf. alexanderi Puthz

S. annularis Erich

\begin{tabular}{rrrrrr}
1 & 1 & 1 & - & - & 3 \\
1 & 1 & - & - & - & 1 \\
1 & 1 & - & - & - & 1 \\
15 & 2 & 2 & 18 & - & 22 \\
\hline 35 & 14 & 10 & 23 & - & 67
\end{tabular}

$663-2-9$

\begin{tabular}{rrrrrc}
8 & - & - & 8 & - & 11 \\
8 & 8 & 2 & - & - & 8 \\
1 & - & 1 & - & - & 1 \\
92 & 87 & 92 & 2 & - & 181 \\
27 & - & - & 27 & 17 & 44 \\
118 & 74 & 70 & 118 & 108 & 367 \\
1 & - & - & 1 & 1 & 2 \\
5 & 4 & 6 & 2 & 1 & 16 \\
116 & 22 & 30 & 116 & 64 & 256 \\
1 & 1 & - & - & 1 & 2 \\
8 & 8 & 3 & 1 & 3 & 15 \\
126 & 126 & 123 & 91 & 56 & 396 \\
23 & 10 & 17 & 23 & 23 & 258 \\
- & 16 & 17 & - & 1 & 103 \\
\hline 534 & 356 & 361 & 388 & 275 & 1650
\end{tabular}

$\begin{array}{llllll}77 & 77 & 72 & 2 & - & 151\end{array}$

$\begin{array}{lllll}10 & 10 & 9 & - & 19\end{array}$

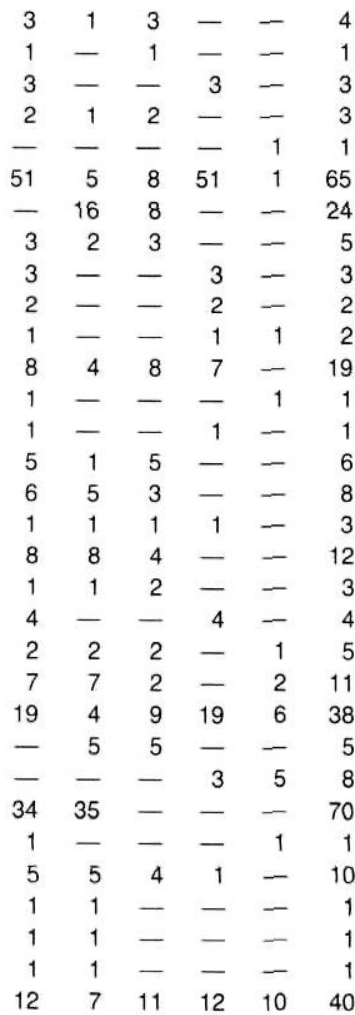




\begin{tabular}{|c|c|c|c|c|c|c|}
\hline Taxon & MNL' & $\mathrm{NLE}^{2}$ & $\begin{array}{l}\text { keleta } \\
\text { NRE }^{3}\end{array}$ & $\begin{array}{l}\text { parts } \\
\mathrm{NPR}^{4}\end{array}$ & & \\
\hline S. brivioi Puthz & 4 & - & - & 4 & - & 4 \\
\hline S. colonus Erich. & 1 & 1 & - & - & - & 1 \\
\hline s. colonus Erich. group & 11 & 11 & - & 4 & - & 25 \\
\hline S. dissentiens Erich. & 2 & - & 2 & - & - & 2 \\
\hline S. cf. dissentiens Erich. & 4 & 1 & 4 & - & - & 5 \\
\hline S. cf. fasciculatus J. Sahl. & 1 & - & 1 & - & - & 1 \\
\hline S. intrusus Csy. & 3 & 2 & 3 & - & - & 5 \\
\hline S. juno Payk. & 7 & 6 & 7 & 2 & 3 & 18 \\
\hline S. laccophilus Csy. & 1 & 1 & - & - & - & 1 \\
\hline S. neglectus Csy. & 1 & 1 & 1 & - & - & 2 \\
\hline S. cf. pauperalus Csy. & 1 & 1 & - & - & - & 1 \\
\hline S. pluto Csy. & 1 & 1 & 1 & 1 & - & 3 \\
\hline S. pumilio Erich. & 6 & 5 & 6 & - & - & 11 \\
\hline S. cf. punctatus Erich. & 7 & - & 7 & - & - & 7 \\
\hline S. reconditus Csy. & 2 & 2 & 1 & - & - & 3 \\
\hline S. cf. reconditus Erich. & 1 & - & 1 & - & - & 1 \\
\hline S. rossi Sand. & 2 & 2 & 1 & - & - & 3 \\
\hline S. cf. rossi Sand. & 2 & - & - & 2 & - & 2 \\
\hline S. cf. schwarzi Csy. & 1 & 1 & - & - & - & 1 \\
\hline S. semicolon LeC. & 1 & - & 1 & - & - & 1 \\
\hline S. sphaerops Csy. & 2 & 2 & - & - & - & 2 \\
\hline S. cf. sphaerops Csy. & 1 & 1 & - & - & - & 1 \\
\hline S. cf. tenuis Csy. & 1 & - & 1 & - & - & 1 \\
\hline S. varipes Csy. & 8 & - & - & - & 8 & 8 \\
\hline S. sp. "X" & 7 & 7 & 6 & - & - & 13 \\
\hline Stenus spp. indet. & 150 & 153 & 169 & 71 & 25 & 418 \\
\hline Staphylinidae gen. indet. & 30 & 74 & 46 & 4 & 4 & 128 \\
\hline Staphylinidae total & 436 & 374 & 380 & 196 & 71 & 1016 \\
\hline
\end{tabular}

\section{PSELAPHIDAE}

gen. indet.

LEIODIDAE

Agathidium spp

\section{SCAPHIDIIDAE}

Scaphisoma sp.

HISTERIDAE

Atholus (Enatholus) sp. Hister $\mathrm{sp}$.

cf. Hister/Margarinotus sp. Maragarinotus sp.

SCARABAEIDAE

Dialytes criddlei Brown gen. indet.

HELODIDAE

Cyphon spp.

\section{HETEROCERIDAE}

gen. indet.

LIMNICHIDAE

Limnichites spp.

ORTHOPERIDAE

Gronevus sp.

$\begin{array}{cccccc}3 & 3 & - & - & - & 3 \\ 1 & - & 1 & - & - & 1 \\ 1 & - & 1 & - & - & 1 \\ 1 & 1 & 1 & - & - & 2\end{array}$
Taxon

(skeletal parts)

$\mathrm{MNL}^{1} \mathrm{NLE}^{2} \mathrm{NRE}^{3} \mathrm{NPR}^{4} \mathrm{NHE}^{5} \mathrm{NFR}^{6}$

\section{CHRYSOMELIDAE}

Altica sp

Chaetochnema spp.

Donacia aequalis Say

$D$. biimpressa Melsch.

$D$. distincta group

D. cf. fuegens LeC.

D. piscatrix Lac.

D. proxima Kby.

$D$. subtilis group

Donacia spp.

Graphops sp.

Macroplea nigrirostris Kby.

Plateumaris cf. chalcea Lac.

$P$. flavipes Kby.

P. cf. emarginata Kby.

P. germani Mann.

P. cf. metallica Ahrens

$P$. pusilla Say group

Plateumaris sp. "X"

Plateumaris spp.

Chrysomelidae total

\section{CURCULIONIDAE}

Acalles cf. carinatus LeC.

Apion spp.

Auleuetes sp.

Bagous cf. americanus LeC

Bagous spp. excl. B. americanus LeC. subfamily Bagoini (excl. B. americanus

LeC.)

subfamily Baridinae

Campilirhynchus spp.

Ceutorhynchus sp.

cf. Contrachelus sp.

Lissorhoptrus spp.

Listronotus spp.

Onychylis cf. nigrirostris (Bohe.)

Onychylis/Endalus spp.

cf. Phytobius leucogaster (Marsh.)

Phytobiini excl. P. leucogaster (Marsh.)

Rhinoncus sp.

Rhynocolus sp.

Sitona sps.

Sphenophorus sp.

$1-1-1-1$ Tanysphirus lemnae Fab.

Curculionidae gen. indet.

Curculionidae total

\begin{tabular}{rrrrrr}
2 & 2 & 1 & - & - & 3 \\
12 & 9 & 12 & - & - & 21 \\
11 & 9 & 11 & 4 & - & 25 \\
1 & 1 & 1 & - & - & 2 \\
16 & 4 & 16 & 8 & - & 44 \\
1 & - & 1 & - & - & 1 \\
1 & - & - & 1 & - & 1 \\
18 & 7 & 6 & 17 & 18 & 56 \\
10 & 2 & - & 10 & - & 12 \\
- & 12 & 9 & 1 & 7 & 31 \\
2 & - & 2 & - & - & 2 \\
7 & 1 & 5 & - & 7 & 13 \\
2 & 2 & 1 & - & - & 3 \\
1 & - & - & 1 & - & 1 \\
2 & 2 & - & 1 & - & 3 \\
3 & - & - & 3 & - & 3 \\
3 & 3 & 2 & - & - & 5 \\
2 & - & - & 2 & - & 2 \\
2 & 2 & - & - & - & 2 \\
2 & 8 & 3 & 3 & 4 & 20 \\
\hline 97 & 64 & 70 & 51 & 36 & 250
\end{tabular}

SCOLYTIDAE

Carphoborus sp.

Hylesinus aculeatus LeC.

Phloeotribus sp.

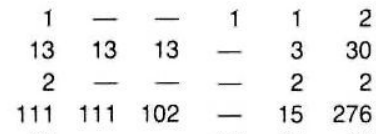

$22-\quad-3329$

\begin{tabular}{rrrrrr}
30 & 92 & 79 & 76 & 52 & 324 \\
2 & - & - & - & 2 & 2 \\
16 & 16 & 11 & - & 1 & 30 \\
3 & - & - & - & 3 & 3 \\
2 & - & - & 2 & - & 2 \\
87 & - & - & - & 87 & 87 \\
47 & 46 & 47 & 40 & 12 & 176 \\
40 & 34 & 28 & 40 & 27 & 149 \\
38 & - & - & 1 & 38 & 39 \\
1 & - & - & - & 1 & 1 \\
4 & - & - & - & 4 & 4 \\
3 & - & - & 3 & 1 & 4 \\
1 & - & - & - & 1 & 1 \\
1 & - & - & - & 1 & 1 \\
3 & - & - & 3 & 3 & 8 \\
8 & 7 & 8 & - & 1 & 16 \\
8 & 10 & 10 & - & 8 & 50 \\
\hline 450 & 329 & 304 & 200 & 391 & 1249
\end{tabular}

Skeletal parts: 1. NMI - Minimum Number of Individuals: 2. NLE - Number of Left Elytra: 3. NRE - Number of Right Elytra; 4. NPR - Number of PRonota: 5. NHE - Number of HEads; 6 . NFR - Number of FRagments. 
from the Innerkip Site are found only in the southern part of Ontario, and also do not reflect a boreal habitat.

The relative percentage of phytophagous insect species decreases with increasing climatic severity. Both Mani (1962) and Downes (1964) commented on this phenomenon, with Downes (1964) noting that the decrease in phytophagous insects was not directly attributable to the availibility of plants, but rather that climate was the limiting factor. Morgan (1973) attempted a correlation of phytophagous species in fossil assemblages in England. In her analyses, the "cold" sites contained $2-10 \%$ phytophagous beetles, while in the "warm" sites this percentage rose to $15-23 \%$. The Innerkip site, by way of comparison, has about $28 \%$ phytophagous species.

From the evidence it is unlikely that the deposit was laid down during a minor fluctuation of the glacial margin but only within a substantial non-glacial period. Unfortunately there is insufficient bio-stratigraphic evidence to state when this nonglacial episode occurred. Some Coleoptera species from the Innerkip Site have also been recovered from the Don Formation in Toronto (Morgan and Morgan, 1980) which is believed to be Sangamonian (Isotope Stage 5e). It should be stressed that the Innerkip insect assemblage bears no resemblance to the Coleoptera assemblages recovered from assumed Early Wisconsinan sites at Woodbridge (Williams et al., 1981), Scarborough (Morgan and Morgan, 1980) or Clarksburg (Warner et al., 1988). These sites may be representative of Isotope stages $5 \mathrm{~d}, 5 \mathrm{~b}$, or 4 . We suggest that the Innerkip site is possibly from Isotope Stage 5, likely from the end of $5 \mathrm{e}$, or alternatively from Isotope Stage $5 c$ or $5 a$.

The presence of the well-preserved deer incisor opens the possibility that, with the discovery of additional teeth from a large mammal, Uranium Series dates might be able to secure the age of the deposit. Further recovery of vertebrate specimens for this purpose and to widen the faunal spectrum and the base for climatic interpretation should be attempted.

\section{SUMMARY}

The Innerkip site contains a well-balanced ecological assemblage of plants, insects and mammals recovered from a relatively thin $(40 \mathrm{~cm})$ peat horizon. Probably the peat accumulated in a small, relatively acidic (no molluscs recorded), marshy pond with abundant aquatic vegetation. The marsh was fringed with sedges, willows and birch. There was little detrital input into the sequence which suggests an effective marginal filtration by plants. There are no beetles indicative of flowing water (Elmidae or Dryopidae), and no plants which prefer mineral substrates.

The vertebrate remains (white-tailed deer, muskrat, Blanding's turtle, meadow vole and possibly a small carnivore) indicate an assemblage such as might be found at the margin of a small pond in southern Ontario today. The age of the deposit ( $>50,000 \mathrm{yr}$. BP), together with the associated temperate insect fauna, suggests that the deposit either formed during the Sangamon Interglaciation (s.s.), or belongs to one of the Early Wisconsinan interstadials.

The animal and plant fossils recovered from the Innerkip Site are particularly important in the Late Quaternary record of southern Ontario and the Great Lakes. Unlike many other similarly aged deposits in the area, these fossils represent animals that were deposited near where they lived and represent a micro-vertebrate local fauna which is a better climatic indicator than an assemblage of the larger and more mobile hardy megafaunal mammals.

\section{REFERENCES}

Banfield, A. W. F., 1974. The Mammals of Canada. National Museum of Natural Sciences, University of Toronto Press, $438 p$

Behler, J. L. and King, F. W., 1979. Audubon Society Field Guide to North American reptiles and amphibians. Alfred A. Knopf Inc., New York, 719 p.

Churcher, C. S. and Karrow, P. F., 1977. Late Pleistocene muskox (Ovibos) from the Early Wisconsinan at Scarborough Bluffs, Ontario, Canada. Canadian Journal of Earth Sciences, 14:326-331.

Churcher, C. S. and Morgan, A. V., 1976. A grizzly bear from the Middle Wisconsin of Woodbridge, Ontario. Canadian Journal of Earth Sciences, 13: 341-347.

Churcher, C. S. and Peterson, R. L., 1982. Chronological and environmental implications of a new genus of fossil deer from Late Wisconsin deposits at Toronto, Canada. Quaternary Research, 18: 184-195.

Coope, G. R., 1968. An insect fauna from Mid-Weichselian deposits at Brandon, Warwickshire. Philosophical Transactions of the Royal Society, London. Series B. 254: 425-456.

Cowan, W. R., 1975. Quaternary geology of the Woodstock area, southern Ontario. Ontario Division of Mines Report 119. Toronto, $91 \mathrm{p}$

Cowan, W. R., Karrow, P. F., Cooper, A. J. and Morgan, A. V., 1975. Late Quaternary stratigraphy of the Waterloo - Lake Huron area, p. 180-222. In Geological Association of Canada Field Excursions Guidebook, Waterloo.

Downes, J.A. 1964. Arctic insects and their environment. The Canadian Entomologist. 96: 279-307.

Dreimanis, A., 1967. Mastodons, their geologic age and extinction in Ontario, Canada. Canadian Journal of Earth Sciences, 4: 663-675.

Hall, E. R., 1981. The Mammals of North America. Edition 2, Volume 2. John Wiley and Sons, p. 601-1188.

Harington, C. R., 1978. Quaternary vertebrate faunas of Canada and Alaska and their suggested chronological sequence. Syllogeus 15, National Museums, Canada, $105 \mathrm{p}$

Kurtén, B. and Anderson, E., 1980. Pleistocene mammals of North America. Columbia University Press, $443 p$.

Lowdon, J. A., Robertson, I. M. and Blake, W. Jr., 1977. Geological Survey of Canada radiocarbon dates XVII. Geological Survey of Canada Paper 77-7. $25 \mathrm{p}$.

Mani, M. S., 1962. Introduction to High Altitude Entomology. Methuen, London.

McAndrews, J. H. and Jackson, L. J., 1988. Age and Environment of Late Pleistocene Mastodont and Mammoth in Southern Ontario. p. 161-172. In R. S. Laub, N. G. Miller and D. W. Steadman, eds., Late Pleistocene and Early Holocene Paleoecology and Archaeology of the Eastern Great Lakes Region. Bulletin of the Buffalo Society of Natural Sciences, Vol. 33, 316 p.

Morgan, A., 1973. Late Pleistocene environmental changes indicated by fossil insect faunas of the English Midlands. Boreas 2: 173-212.

1988. Late Pleistocene and Early Holocene Coleoptera in the Lower Great Lakes Region. p. 195-206. In R. S. Laub, N. G. Miller and D. W Steadman, eds., Late Pleistocene and Early Holocene Paleoecology and Archaeology of the Eastern Great Lakes Region. Bulletin of the Buffalo Society of Natural Sciences, Vol. 33, $316 \mathrm{p}$.

Morgan, A. V. and Morgan, A., 1980. Faunal assemblages and species shifts of Coleoptera during the Late Pleistocene in Canada and the northern United States. The Canadian Entomologist, 112: 1105-1128.

Peterson, R. L., 1965., A well-preserved grizzly bear skull recovered from a Late Glacial deposit near Lake Simcoe, Ontario. Nature, 208: 1233-1234. 
1966. The Mammals of Eastern Canada Oxford University Press. Toronto, $465 \mathrm{p}$.

Pilny. J. J. and Morgan, A. V., 1987. Paleoentomology and paleoecology of a possible Sangamonian site near Innerkip. Ontario. Quaternary Research, 28: $157-174$.

St-Onge, D., 1987. The Sangamonian Stage and the Laurentide Ice Sheet. Geographie physique et Quaternaire, 41: 189-198.

Warner, B. G., Morgan, A. V. and Karrow, P. F., 1988. A Wisconsinan Interstadial Arctic flora and insect fauna from southwestern Ontario. Canada. Palaeogeography, Palaeoclimatology, Palaeoecology, 68: 27-47.
Williams, N. E., Westgate, J. A., Williams, D. D., Morgan, A and Morgan, A. V. 1981. Invertebrate fossils (Insecta: Trichoptera, Diptera, Coleoptera) from the Pleistocene Scarborough Formation at Toronto, Ontario, and their paleoenvironmental significance. Quaternary Research, 16: 146-166.

Wilson, M. C. and Hills, L. V., 1984. Holocene white-tailed deer (Odocoileus virginianus) from the foothills northwest of Calgary. Alberta, Canada. Canadian Journal of Earth Sciences, 21: 365-371

Zichmanis, Z and Hodgins, J., 1982. Flowers of the wild: Ontario and the Great Lakes Region. Oxford University Press, Toronto, $272 \mathrm{p}$. 